\title{
IMPOSITION OF ANTIDUMPING DUTY (BAMD) TOWARDS CHINA'S COLD ROLLED COIL/SHEET (CRC/S) PRODUCTS
}

\author{
Lila Pratiwi*
}

\begin{abstract}
Steel industry is a strategic sector in the economy of a country. Steel industry in Indonesia has not been able to fulfill their domestic demand that is still necessary to import steel product. However, many of these imported products are sold at dumping prices, especially those from china giving rise to unfair trade. One of trade remedy measures as a result of unfair trade remedies can recover trough the imposition of antidumping duty. In 2013, Indonesia imposes antidumping duty for Cold Rolled Coil/ Sheet (CRC/S) from China and other countries. Imposition of antidumping duty will be analyzed descriptively with the antidumping agreement conformity. While, it cannot be denied that political factors also determine imposition of antidumping duty. It is need to use analytical theory of justice in order to enforce fair-trade
\end{abstract}

Key words: unfair trade, trade remedy, dumping, antidumping duty

\section{Introduction}

Global recession in the 1980s has been change a lot of countries of protection mechanism related to its domestic industry. Mechanism of protection against domestic industry was originally a high entry tariffs, quota restrictions, and other-barriers such as non-tariff barriers, are now likely to use anti-dumping instrument. ${ }^{1}$ In addition, the anti-dumping mechanism is used in order reprisals for acts of dumping by industries in other countries. Retaliation is done because Dumping is considered adverse effect. Dumping resulting broad impacts on the economy, which caused harm to the company's competitor offender dumping in the importing country. Impact of dumping is harmful to the domestic industry market share and monopolizing power market by dumping product. ${ }^{2}$ The destruction of the domestic industry will affect the country's economic growth. Therefore the protection of the domestic industry needs to be done through the anti-dumping measures. Australia, Canada, European Union countries and the United States are 'traditional users' anti-dumping mechanisms in the 1980s. Four countries known as the 'Big Four' in the application of anti-dumping mechanism, in which $90 \%$ of anti-

\footnotetext{
* Researcher at the Center for International Law Studies, Faculty of Law Universitas Indonesia.

${ }^{1}$ Mark Wu, "Antidumping in ASIA's Emerging Giants", Harvard International Law Journal, Winter 2012. p. 3

${ }^{2}$ Raj Bhala, Internatinal Trade Law: Interdisciplinary Theory and Practice, Third Edition, Lexis Nexis.2001. p. 883
} 
dumping actions performed by the four countries. ${ }^{3}$ After more than two decades, the use of anti-dumping has expanded rapidly. Although initially the anti-dumping mechanism deliberately designed to protect industrial developed countries, but currently its use is not dominated by developed countries itself. Once the world Trade Organization or the World Trade Organization (WTO) was formed and became effective in 1995 recorded developing countries began actively anti-dumping actions.

Nevertheless, cases of anti-dumping on the world market are concentrated in a few industrial sectors, one of them which are the steel industry. This is reinforced by the data from the WTO in 1995-1999 where there were recorded $40 \%$ anti-dumping measures imposed for metal-based industries. ${ }^{4}$ In Indonesia, initiation of anti-dumping is handled by the Anti-dumping Committee Indonesia (KADI). The existence of the steel industry and its supporting industries are very important for developed and protected by each state. This sector plays a major role in supplying vital raw materials for development in various fields ranging from infrastructures (buildings, roads, bridges, electricity and telecommunications networks), production goods (machinery and plant material and spare parts support), transport equipment (ships marine, rail and rails, automotive), to weaponry. These important roles of steel industry are a very strategic sector for prosperity of a country. ${ }^{5}$

Currently, the largest steel producer in the world is still occupied by China with 650 million tons steel production. China owns 44\% of the World steel production, followed by Japan with the proportion of production by $8 \%$ of the World production and U.S. with a production of $6 \%$ total of the World steel production. ${ }^{6}$ Indonesia consumes high level of steel which is can not fulfill by domestic steel production and the domestic steel market is still deficit where there is over demand both in the upstream, intermediate and downstream. The magnitude of the steel industry markets are fulfilled by imported steel from China. ${ }^{7}$ The international steel prices in the international market, China influencesit due to the magnitude of the dominance of China's steel production.

With a large volume of steel production, China,,ssteel products flooded the world steel markets, including Indonesia. Many China,,s steel products sold in Indonesia at dumping prices, can threatening the domestic steel producers. Therefore, Indonesia is very concerned to protect domestic steel products from the dumping products. Recently, Indonesia imposes of Antidumping Duty in 2013 is Cold rolled steel sheet products (CRC / S) from Japan, the Republic of Korea, Taiwan, Republic of China, and the Socialist Republic of Vietnam. Under these circumstances, this article will be analyzeabout,,

1. Conformity procedures for the imposition of BMAD Cold rolled steel sheet products (Cold Rolled Coil / Sheet (CRC / S)) originating People's Republic of China, in accordance with the Anti-dumping Agreement

2. The impact of the entry of CRC/S products sold at dumping prices in Indonesia

\footnotetext{
${ }^{3}$ Inge Nora Neufeld, “Antidumping and Countervailing procedures-use or Abuse? Implications for Developing Countries”,UNCTADPalais des Nations 1211 Geneva Switzerland, 2001. p. 9

${ }^{4}$ Inge Nora Neufeld, Op.cit. p. 10-11

${ }^{5}$ Pengembanganinvestasilogamdasar. p. 1

${ }^{6}$ Ibid p. 16

${ }^{7}$ Ibid.hlm. 10
} 
3. In the legal aspect, the effort must be taken to avoid the impact of the Indonesian government dumping harmful products to domestic production in the context of fair trade

This article using "Theory of Justice" in the analysis related retaliation as a result of unfair trade. Gracia argues in his article "Building a Just Trade Order for a Millenium" that the international economic law also includes a mechanism for the identification and correction of the profits earned by the unnatural way through the dispute resolution based on multilateral agreements. ${ }^{8} \mathrm{BMAD}$ imposition mechanism by which committee is seen as an inter-state application of corrective justice to the situation in which the question of profit by a business entity in the state or a country. This article using the law of normative legal research methods to understands the application of norms of law to the facts. ${ }^{9}$ Through these methods will be conducted analysis of the issues and compliance with the relevant statutory requirements.

\section{Analysis}

\section{Rationale Anti-Dumping measures}

The rationale for anti-dumping actions the world community have an economic system different from one another. Given these differences then what are considered unfair in one country may be considered sebgai something perfect for other countries. However, in a different system there is also a mutual dependence between the one with the other. Interdependence between the different systems can cause economic losses for some countries. ${ }^{10}$ In addition to the different economic systems, fair trade is hard to achieve due to the fact that the perpetrator is in a position to trade different economic power. The economic strength of a country influence the forces affecting the world market. In addition to the economic strength perebedaan can cause unfair trade, it can also occur due to fraudulent practices and protection policies. Trade be fair if the government does not create barriers to prevent foreign products entering their country. It is unfair to foreign manufacturers as well as for domestic consumers if the product is made barriers to foreign entry. To bridge the inequality in trade between developed and developing countries made a set of trade agreements in the world, in order to achieve fair trade. Additionally necessary needed instrument governing trade practices due to unfair recover states due to unfair practices. International legal regime in order to bridge developed and developing contrries in trade is through the establishment of World Trade Organization (WTO)

WTO as the global trade organization that regulates trade members aim to create a fair trade. Organization formally established under the Marrakech Agreement Establishing the World Trade Organization agreed on 15

\footnotetext{
${ }^{8}$ AgusBrotosusilo, DesertasiGlobalisasiekonomidanperdagangan international: studitentangkesiapan hokum Indonesia melindungiproduksidalamnegeri me/aluiundang-undang Anti-dumping dan safeguard, , Universitas Indonesia, 2005.p.15

${ }^{9}$ Ibid.

${ }^{10}$ Candido Tomas GraciaMolyneux, Domestic Structures and Internatinal Trade, the unfair trade Instruments of US and EU, Oxford Portland Oregon, 2001, p.10
} 
April 1994, and effective as of January 1, $1995 .{ }^{11}$ WTO in order to achieve the purpose of fair trade is expressly written in the Treaties Preambuleditegakannya through the principle of reciprocity or reciprocity. Reciprocity is a fundamental form of retaliation in WTO. Retaliation is an act of retaliation for not compliance decisions dispute resolution body or a trade recovery actions (trade remedy) either as a result of unfair and fair trade. WTO Trade Remedies identify three types, one of which is an anti-dumping. In establishment comprehensive regulations governing anti-dumping in the Government of Indonesia as a member of the WTO later issued Government Regulation No. 34 Year 2011 regarding the duties of BMAD and benefits as the implementation of the Anti-dumping Agreement.

\section{product \\ 2. Imposition of anti-dumping duty (BMAD) towards China s CRC/S}

Imposition of anti-dumping duty (BMAD) toward China s CRC/product has just issued its decision on March 2013 through the Decree of the Minister of Finance No.65/PMK.011/2013. The BMAD imposition filed by PT. Krakatau Steel as petitioner alleges the practice of dumping of the product CRC / S imports from Japan, the Republic of Korea, Taiwan, Republic of China, and the Socialist Republic of Vietnam, with a discussion of the larger portion of the imports from China.

The petition was filed with products based on import data of CRC / S during the past four years, from 2007 to 2010, which showed a significant increase. With these improvements, its also proves that the CRC / Snational consumption increase. However, this increase was more much filled by imported products that have an impact on product terdesaknyaCRC / S domestic.

The growth of CRC/Simport products fluctuate quarterly, but the average quarterly imports showed a tendency to increase.Total imports of CRC/S during January to December 2010, which can be produced domestically and also has the HS number that alleged dumping reaches $71.87 \%$. Its presence is disturbing markets ofCRC/S product produced by domestic manufacturers. While the remaining $28.13 \%$ of total imports are CRC/S importthat can not produced domestically. ${ }^{12}$

CRC/S imports that fullfildomestik market suspected saled with dumping price. Based on existing data import the country with imports share more than $3 \%$, which is the initial criteria toinvestigate countries suspected dumping practices are as follows: ${ }^{13}$
a) Japan $32.96 \%$
b) People's Republic of China 24.92\%
c) Republic of Korea $17.30 \%$
d) $15.5 \%$ Taiwan
e) $3.90 \%$ Vietnam

By looking at the CRC/S imports data during three years and regarding to the requirements of dumping allegations, the five countries that have total

\footnotetext{
${ }^{11}$ Peter Van Den Bossche, The Law and Policy of the World Trade Organization, Text, Cases and Material, Second Edition, Cambridge University Press, New York, 2008, p. 42

${ }^{12}$ Petisi Anti-dumping PT. Krakatau Steel (Persero) tbk, Jakarta 2010 (Non-Confidential Complain).

${ }^{13}$ Sumber BPS Indonesia dalamPetisi . Anti-dumping PT. Krakatau Steel (Persero) tbk, Jakarta 2010 (Non-Confidential Complain)
} 
importmore than $3 \%$ suspected cause material injury as well as a threat to the survival of the national steel industry in the future. Under that circumantances Petitioner filed this petition.

Imposition of BMAD to the CRC/S product is started on June 24, 2011 when Anti-dumping Committee Indonesia (KADI) received the petition to investigate by PT. Krakatau Steel as a representative of the Domestic Industry. That the results of research conducted, the authors did not obtain the data related to the calculation of dumping margins, to China and accused of dumping the other by reason of confidentiality. However, based on the testimony presented by KADI is in its final report, it can concluded that the method used for the calculation is in accordance with the provisions of the Anti-dumping Agreement. As these provisions that the imposition of anti-dumping requisite duties are:

\section{a) Proven existence of dumping}

KADIscalculation methods of the dumping margin is in accordance with the provision of the Anti-dumping Agreement. The method is performed in determining the existence of dumping, as folows:

1. Like product

Cold Rolled Coil/Sheet (CRC/S) which is produced by the applicant is of similar goods (like product) with $\mathrm{CRC} / \mathrm{S}$ which is imported from countries accused.

2. Normal value (nv) and Export Price (ep) calculated by constructing nv and invormationep based on best available data. (Because the Chinese company was not cooperative in providing information)

3. Dumping Margin formula

$$
\begin{aligned}
& \text { Dumping margin }=\text { Normal Value }- \text { Export Price } \\
& \mathrm{X} 100 \\
& \text { Export Price (CIF) }
\end{aligned}
$$

b) Material injury

Any material injury suffering by the domestic industry is proven by the trend of domestic sales that declined up to $8.64 \%$ due to an increase in dumped imports. Financial injury increased significantly over a period of three years and this is caused by the dumped imports of goods whose price is not only below the price of Applicant (Price Undercutting), but also price below the cost of applicant (Price Suppression.) In terms of employment, total employment is relatively stable during period of three years and an increase in wages due to government regulation that raises the minimum wage.

c) Causal link.

1. Volume effect

The impact of an increase in volume is calculated both in absolute and relative volume.

2. Price effect 
Financial injury increased significantly over a period of three years and this is caused by the dumped imports of goods whose price is not only below the price of Applicant (Price Undercutting), but also price below cost of applicant(Price Suppression). There is also price depression during the period of investigation because of pressure from the dumped imports of goods increased.

However, regadarding toKADI Final Report and the Regulation of the Minister of Finance of the Republic of Indonesia No.65/PMK.011/2013 hence there is a significant difference in the amount of BMAD between them. This suggests that the committee recommendation is based on available evident, it still has the potential to change at the ministerial level. Inministerial level, the imposition of BMAD is also considering the national interest. As in the case of CRC/S, where the national steel demand can not be fullfied entirely by the domestic steel industry that makes Indonesia requires steel market through imports. Especially for high quality CRC/S product which is can not be produce by local producers. So feared that the imposition of BMAD which too high, resulting lack of stock CRC/S domestic.

\section{Dumping Impact to CRC/S Domestic Industries}

The existence of CRC / S imports with dumping price mainly from China makes the domestic industry lost their market. Efforts imposition BMAD as a counter balance for the actions of cheating may provide an opportunity for the domestic industry to recover their businesses due to the actions undertaken dumping exporters. With the BMAD imposition toward CRC/S import resulted import volume such importroduct which entered the domestic market is decline. The decline in imports of like product proves that the anti-dumping mechanism is effective in curbing imports. Therefore, period of the decline in imports product isis an opportunity to domestic industryto recover. In addition to the injury caused CRC / S imports at dumping prices is a serious threat to the survival of the domestic steel companies.In case of steel industry in the country colleps, it will affect the national economy growth. That is because the steel industry is a strategic sector and is the backbone of a country as well as a large enough role in the growth of the national economy. Steel industry has an influence on national economic growth because:

1. Steel industry is a "labor intensive" industry, when the steel industry colleps then unemployment will increase and will be a burden for the state.

2. Steel industry making a contribution to the government's foreign exchange in significant amount.

3. The location of the steel industry mostly in the country side, then the presence of this industry is the livelihood of the communities near the plant (community).

However, the imposition BMAD is temporerly, when the period of BMAD imposition has finished, imported products will flooding back to the domestic market. In addition, imported products come in a variety of ways due to circumvention practices that no requiremnets in the Anti-dumping Agreement and national regulations to regulate circumvention. 


\section{Effort taken by the Government to Overcome the Impact of Dumping}

To recover the domestic industry as a result of fraudulent trading of $\mathrm{CRC} / \mathrm{S}$ then it necessary remedy actions such as the imposition of anti-dumping duties (BMAD) towards products that proven sold in the dumping price. Related to this, the Government has imposed BMAD through Regulation of the Minister of Finance of the Republic of Indonesia No.65/PMK.011/2013 about BMAD Against Imposition of CRC/S Imported from Japan, Republic of Korea, Taiwan, Republic of China, and Socialist Republic of Vietnam.

\section{Others problems in the imposition of BMADCRC/S against China}

BMAD imposition to CRC/S is suspectedto several countries. Each country has different problems with the committee. Some of the problems that occurred in this case are as follows:

a. That in this dispute involving many parties. And also many parties that are not cooperative. In this dispute, the Chinese companies are the most not cooperative parties. ${ }^{14}$

b. That the Japan and Korea is a country that does great political pressure on the Indonesian government (sometimes it called negotiation). Japanese government continued political pressure both before and after the release of esssentialfact. The political pressures make this case is a sensitive case for the Government of Indonesia to the secretive almost all data and information.

Reasons uncooperative attitude of the Japanese due to:

i. Japan questioned the legal standing of the applicant.

ii. Japan argues that their CRC/S product and the applicant is not like product because it does not directly compete and have a different market share with CRC/S Applicant production. So it does not meet with the requirements to like product as set forth in Article 2.6 Anti-dumping Agreement which states: ${ }^{15}$

'throughout this Agreement the term 'ike product' J'produitsimilaire') shall be interpreted to mean a product which is identical, i.e. alike in all respects to the product under consideration, or in the absence of such product, another product which, although not alike in all respects, has characteristics closle resembling those of the product under consideration"

Referring to such article there is no clear parameters regarding the like product. Therefore, each party in a dispute can determine justification regarding like product the interpretation. The determination of the type of goods that are not identical, but resemble the overall characteristics and almost like, there are factors that are considered in determinate the nature and extent of a competitive relationship of these items. Ithis case the Japan CRC/S product and applicant CRC/S product apparently substitutable, although physical characteristics, manufacturing process and different chemical content.

On the other hand the government of Indonesia considers that CRC/S

\footnotetext{
${ }^{14}$ Ibid

${ }^{15}$ HasilWawancaradenganKementerianPerindustrianRepublik Indonesia tanggal 14 Juni 2013
} 
products in this case are similar products because although not exactly the same but CRC products Petitioner and Japan are subtitutable. At first allotment CRC/S from Japan is different from Applicant product. Japan CRC/S Product has better quality with lower price when compared to the Applicant product. So such conditions cause injury to the Petitioner because consumers switched to using CRC/S from Japan replaces Applicant product. In other words, although the two are not exactly the same product and use a different, ultimately both products are substitutable.

c. That Korea feel that the imposition BMAD was not appropriate and is considered too high, then Korea made another attempt by the national courts. In the case of Korea filed to the District Court.

d. That there is an agreement IJEPA (Indonesia-Japan Economic Partnership Agreement) effective July 1, 2008. With the IJEPA then applied tariff cut to $0 \%$ for Japan CRC/S products.

Tariff cut for Japan CRC/S product applied by the government with consideration that domestic steel industry has not been able to produce CRC/S with high quality for raw materials which are used for automotive. CRC/S which produced the domestic industry is CRC/S whose quality is not destined for the automotive industry but to make roof, and electronic packaging that does not require a high level of quality steel. However, the lack of government oversight of the products included in the tariff is low due IJEPA, resulting Japan CRC/S products that designated as automotive materials market flooded $\mathrm{CRC} / \mathrm{S}$ market used for roofing and electronic packaging.

The flood high quality CRC/S with low price for a zero tariff finally interfere the market share of Petitioner, because of consumers tend to choose high quality CRC/S with low prices although will not used for the automotive industry.

\section{Conclusions and Recommendations}

The flood of CRC/S which is sold at dumping prices in the domestic market make the domestic industry, represented by PT. Krakatau Steel feels aggrieved. Therefore PT. Krakatau Steel submitted a pettition referred to the CRC/S product from Japan, the Republic of Korea, Taiwan, Republic of China, and the Socialist Republic of Vietnam. Committee is to undertake investigations in the case of CRC/S in particular for which came from China, has been in accordance with the provisions of the Anti-dumping Agreement. As these provisions that the imposition of anti-dumping requirements that proved the existence of dumping duties, there is a material injury for domestic industry and a causal link between the injury and the imports at dumping prices. The recommendation of committee relating to BMAD has the significant changes at ministerial level based ministerial considerations of national interest. As in the case of CRC/S, where domestic steel demand can not be fullfiled entirely by the domestic steel industry that Indonesia market still requires steel through imports, especially for high quality CRC/S. The imposition of BMAD that too high considerably resulted in a lack of National CRC/S stock.

The existence of CRC/S imports in dumping price mainly from China 
makes the domestic industry lost their market. This resulted in the domestic industry suffered injury. If no effort on the practice of dumping the domestic industry will colleps. However, this mechanism is temporary. In addition to imported products come in a variety of ways due to circumvention practices that no requirement relating circumvention in the Anti-dumping Agreement and national regulations.

Efforts to restore the state as a result of fraudulent trading products $\mathrm{CRC} / \mathrm{S}$ is a remedy action is through the imposition of anti-dumping duties against products that prove to be sold in the price dumping. BMAD such as the imposition of counter balance the fraudulent action may provide an opportunity for the domestic industry to restore their businesses due to the actions undertaken dumping exporters. Related to this, the Government has imposed BMAD through Regulation of the Minister of Finance of the Republic of Indonesia No.65/PMK.011/2013 about BMAD Against Imposition ofCRC/S Import from Japan, Republic of Korea, Taiwan, Republic of China, and Socialist Republic of Vietnam.

In my opinion, imposition BMAD is not enough to recover the condition of the domestic industry suffered injury due to product CRC/S at dumping prices. Circumvention of the practice and the absence of domestic arrangements to address the problem lies led to the imposition of BMADwill be ineffective. So,it needs the circumvention provisions set in national regulations. In addition integrated efforts are needed by all stakeholders to improve the competitiveness of the domestic industry so it is not easy to be colleps when compete with the imported products that are sold at dumping prices and also can fullfil domestic demand.

\section{Bibliography}

\section{Books}

AgusBrotosusilo. DesertasiGlobalisasiekonomidanperdagangan international: studitentangkesiapanhukum Indonesia melindungiproduksidalamnegerimelaluiundang-undang anti dumping dan safeguard. Universitas Indonesia, 2005.

AgusBrotosusilo, et.al., PenulisanHukum: BukuPeganganDosen. Jakarta: KonsorsiumIlmuHukumDepartemenPDK, 1994, hlm. 8, dalamRingkasanDisertasiAgusBrotosusilo, FakultasHukumUniversitas Indonesia, 2006

AgusBrotosusilo, FilsafatHukum, FakultasHukum Program Magister Hukum, Universitas Indonesia, 2012.

Bhala, Raj. International Trade Law: Theory and Practice (Second Edition), Lexing Publishing, United States, 2001.

Internatinal Trade Law: Interdisciplinary Theory and Practice. Third Edition. Lexis Nexis. 2001.

Bossche, Peter Van Den. The Law and Policy of the World Trade Organization, Text, Cases and Material, Second Edition, Cambridge University Press, New York, 2008,

Bossche, Peter van den, DaniarNatakusumahdan Joseph WiraKoesnaidi, PengantarHukum (WTO) World Trade Organization, YayasanObor Indonesia, 2010. 
Bown, Chad P. and JoostPauwelyn, The Law, Economics and Politics of Retaliation in WTO Dispute Settlement, Cambridge University Press, New York. 2010.

ChristoporusBarutu, Ketentuan antidumping, subsidi, dantindakanpengamanan (safeguard) dalam GATT dan WTO, PT. Citra Aditya Bakti, Bandung 2007.

Czako, Judith, Johann Human and Jorge Miranda, A Hanbook on Anti-Dumping Investigations, Cambridge University Press, 2003.

Erry Bundjamin, Upaya-upayaDibidangHukumPerdaganganInternasional, Program PascaSarjanaFakultasHukumUniversitas Indonesia, Jakarta, 2012.

Lie ,Yong-Shik. Safeguard Measure in World Trade, The Legal Analysis. Kluwer Law Internatinal. New York, 2003.

Marceau, Gabrielle. Anti-Dumping and Anti-Trust Issues In Free Trade Areas, Claredon Press Oxford, 2001

Molyneux, Candido Tomas Gracia. Domestic Structures and Internatinal Trade, the unfair trade Instruments of US and EU, Oxford Portland Oregon, 2001.

Teh, Robert, Thomas J. Prusa and Michele Budetta, Trade Remedy Provisions in Regional Trade Area, Staff working Paper ERSD-2007-03, World Trade Organization Economic Reaserch and Statistic division, September 2007 SoerjonoSoekanto. PengantarPenelitianHukum. UI-Press, 2008.

ValerineJ.L.K, ModulKuliahMetodePenelitianHukum. (Jakarta: PascaSarjanaFakultasHukumUniversitas Indonesia, 2009).

W.J.S. Poerwadarminta, KamusUmumBahasa Indonesia, Jakarta: BalaiPuataka, 2002.

\section{Journal}

ArghanaAggarwal, Antidumping Law and Practice: an Indian Prespective, april 2002,

Alan 0. Sykes, Trade Remedy Laws, John M. Olin, Law \& Economics Working Paper No. 240, The Law School the University of Chicago, April 2005,

Bagwell, Kyle. Remedies in The World Trade Organization: an Economic Perspective. Departement of Economics, Columbia University. New York. 2007

Bolton, Reid M. Anti-dumping and Distrust: Reducing Anti-dumping Duties Under the WTO trough Heightened Scrutiny, Berkeley Journal of International Law, 2011.

ErryBundjamin, Law Economic Public Policy, The ten major problems with the Anti-dumping Instrument in Indonesia, Journal of World Trade Vol.39. no 1 February 2005.

Krishna, Raj. Antidumping in Law and Practice. Legal Reform and Advisory Services Division, Legal Department.1999

Neufeld, Inge Nora. "Antidumping and Countervailing procedures-use or Abuse? Implications for Developing Countries”.UNCTADPalais des Nations 1211 Geneva Switzerland, 2001 
Ostoni, Lucia, Anti-Dumping Circumvention in the EU and the US: Is There a Future For Multilateral Provisions Under WTO?, Fordham Journal of Corporate \& Financial Law, Volume 10. Issue 2, 2005.

Wu, Mark. "Antidumping in ASIA's Emerging Giants". Harvard International Law Journal. Winter 2012.

\section{Publications}

World Steel Association, Economic Committee, Steel Statistical Yearbook 2012, Brussels, 2012

AchdiatAtmawinata. "KedalamanStrukturIndustri yang Mempunyai Daya Saing di Pasar Global, TelaahKedalamanStrukturIndustri Engineering Prioritas (Industri Baja danIndustriLogam Non-Ferrous)". Jakarta 2010 Pengembanganinvestasilogamdasar

DepartemenPerindustrianRepublik Indonesia. Media industry. "StrategiMemperkuat Industry Baja Nasional No. 02. 2008”, 2008

DirektoratPengamananPerdagnaganDirektoratJendralPerdagnagnLuiarNegeriKementerianPerdagnangan, PengamananEksporAksesPasar, BimbinganTeknisPenyelidikan Anti Dumping, 2013

PengumumanKomite Anti Dumping Indonesia No. 415/KADI/VI/2012

Petisi Anti-dumping PT. Krakatau Steel (Persero) tbk, Jakarta 2010 (Non-Confidential Complain).

LaporanAkhirHasilPenyelidikan Antidumping terhadapbarangimpor Baja LembaranCanaiDingin (CRC/S) asalJepang, Korea Selatan, Republik Rakyat China, Taiwan dan Vietnam, KADI, Desember 2012

\section{Regulations}

Marakesh Agreement

Antidumping Agreement

Law No. 7 of 1994 onRatification ofAgreement Establishing the World Trading Organization 